\title{
Malignant Pilomatricoma: Two New Observations and Review of the Relevant Literature
}

\section{Malign Pilomatrikoma, İki Yeni Gözlem ve İlgili Literatürü Gözden Geçirme}

\author{
Mohamed ALLAOUI ${ }^{1}$, Elie HUBERT ${ }^{2}$, Jean-Jacques MICHELS ${ }^{1}$ \\ 'Department of Biopathology, François Baclesse Cancer Center, CAEN, FRANCE \\ ${ }^{2}$ Department of Pathology, Louis Pasteur Hospital, CHERBOURG, FRANCE
}

\begin{abstract}
Malignant pilomatricoma or pilomatrical carcinoma is a rare malignant hair follicle neoplasm. This tumor is locally aggressive with increased tendency to recur, but a low metastatic potential. Its histopathological diagnosis is difficult and based on a detailed evaluation of the infiltrative nature, the importance of the mummified and necrotic cell component, atypical mitoses, and perineural or vascular invasion. Surgical wide resection is the recommended treatment. It reduces the risk of focal recurrence by $50 \%$. Here we report two new cases including one that occurred on a lesion initially diagnosed as benign pilomatricoma.
\end{abstract}

Key Words: Pilomatrixoma, Hair follicle, Adnexal and skin appendage neoplasms

\section{ÖZ}

Malign pilomatrikoma ya da pilomatrikal karsinom, nadir görülen bir malign kıl follikül neoplazmıdır. Bu tümör, artmış nüks eğilimi olan lokal agresif bir tümördür ancak metastaz potansiyeli düşüktür. Tümörün infiltratif yapı, mumifiye ve nekrotik hücre komponenti, atipik mitozlar, perinöral veya vasküler invazyon temelinde gerçekleşen histopatolojik tanısı zordur. Tedavide geniş cerrahi rezeksiyon önerilmektedir. Bu tedavi, lokal nüksü \%50 oranında azaltır. Bu makalede, biri başlangıçta benign pilomatrikoma tanısı almış, iki yeni olgu sunulmuştur.

Anahtar Sözcükler: Pilomatriksoma, Kıl follikülü , Deri eklentileri ve uzantıları tümörleri

\section{INTRODUCTION}

Pilomatricoma or pilomatrixoma is a benign adnexal tumour. Recently a rare malignant variant has been individualized: malignant pilomatricoma or pilomatrical carcinoma. This is a locally aggressive tumour which tends to recur, but with a low potential for systemic metastasis (13 ). We describe two new cases, one of them occurring on a lesion that initially diagnosed pilomatricoma.

\section{CASE REPORTS}

Case 1: Ms R, 63 years, consulted her physician in October 2009 for a $5 \mathrm{~cm}$, multinodular lesion of the outer side of the right thigh, appearing 3 months previously.

The first biopsy revealed a usual form of pilomatricoma. Six months later, the lesion recurred, with a swift growth attaining $6 \mathrm{~cm}$. The new biopsy showed a poorly circumscribed dermal tumor that composed of basaloid

(Turk Patoloji Derg 2014, 30:66-68)

Received : 10.08.2013 Accepted : 20.08.2013 cell with focally pleomorphic nuclei and frequent mitoses. Some mitoses were atypical and there was significant mitotic activity (38 mitoses per 10 high-power fields). There was no connection to the epidermis. The center of the sheets contained rather abundant necrosis and areas of mummified cells leading to a diagnosis of malignant pilomatricoma, despite the lack of vascular invasion or perineural involvement (Figure 1,2).

An excision with a $1 \mathrm{~cm}$ wide margin was made. No inguinal lymphadenopathy was noticed. No event occurred up to now (2 years of follow-up).

Case 2: Ms F. 66 years, consulted her physician in March 2012 for a $1.5 \mathrm{~cm}$ nodule of the left upper eyelid, noticed for one month. On microscopy: there was malignant pilomatricoma, with a proliferation of atypical basaloid cells with numerous mitoses (Figure 3), tiny areas of necrosis and mummification. A wide excision with a security margin

Correspondence: Mohamed ALLAOUI

François Baclesse Cancer Center, Department of Biopathology,

CAEN, FRANCE

E-mail: allaoui.m1@gmail.com Phone: +21 2666103981 


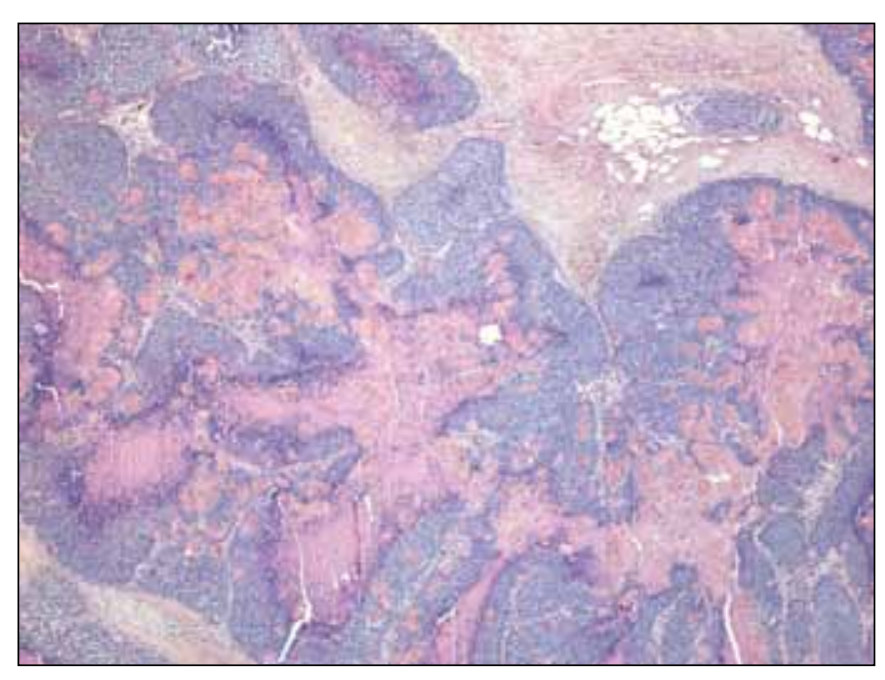

Figure 1: Multinodular basaloid proliferation in dermis. Large areas of necrosis and shadow cells nests are evident (H\&E x40).

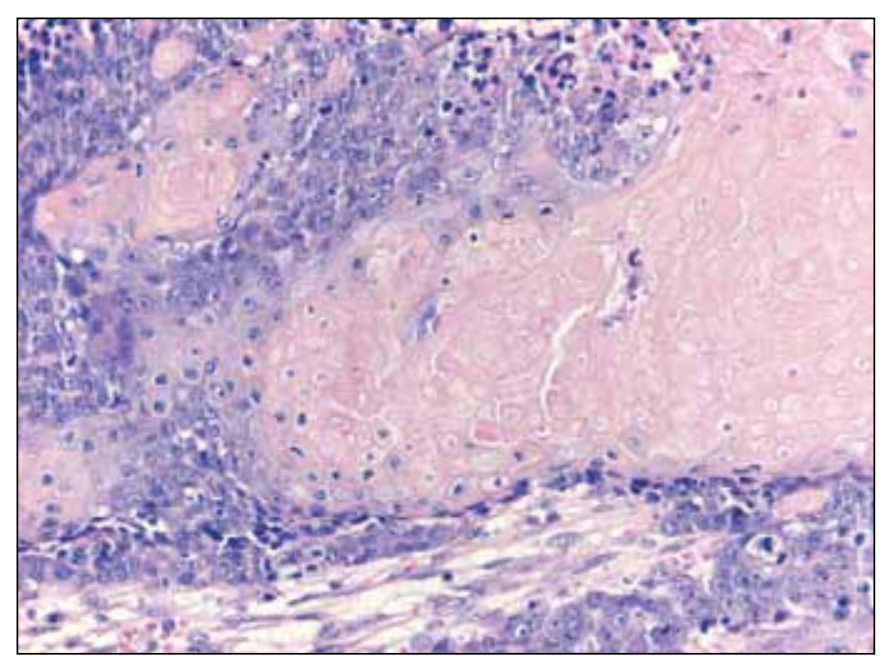

Figure 2: Foci of transitional cells and shadow cells (H\&E x200).

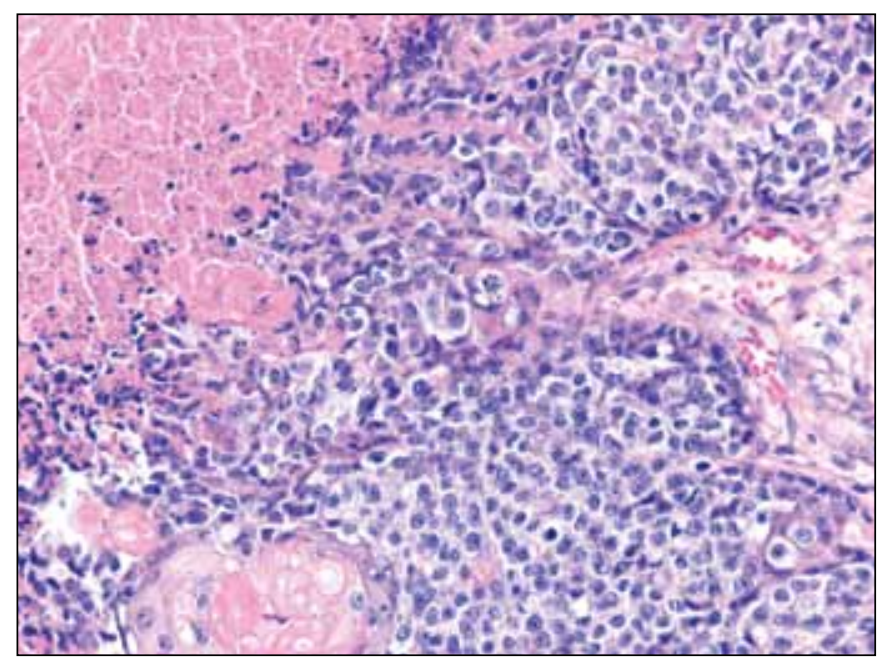

Figure 3: Hyperchromatic and pleomorphic basaloid cells, with abundant necrosis (H\&E x200). was performed, without a following event but a very short follow-up of several months only.

\section{DISCUSSION}

Described in 1980 by Lopansri and Mihm, the malignant pilomatricoma is a rare hair follicle carcinoma (2). To the best of our knowledge, about 80 cases have been reported in the literature. This lesion occurs more often in the elderly, as was the case for both our patients. The appearance of a pilomatricoma in the elderly can be viewed with suspicion, but is not tantamount to malignancy, because there exists a second peak of frequency between the 6 th and 7 th decades (3-5).

The clinical distinction between benign and malignant pilomatricoma is rather difficult (same presentation and same preferential cephaliclocalization) (4). Macroscopically, the tumour shows a reddish, rather firm and lobulated aspect $(4,5)$. Histologically, it is a pilomatricoma with sheets of basaloid cells evolving towards mummification with sometimes calcifications. Malignancy is certain when the tumour has the following features: poor circumscription, nuclear atypia and atypical mitoses, areas of massive necrosis, infiltration of the hypodermis, dermis or cartilage with sometimes perineural and/or vascular invasion (3-10).

A distinct entity of pilomatricoma, called, 'proliferating pilomatricoma' or 'atypical pilomatricoma' has been proposed by Kaddu et al. in $1997(11,12)$. This variant occurs mainly in middle-aged adults and the elderly $(11,12)$ and to date, very few cases of proliferating pilomatricoma were described in the literature.

Morphologically, the proliferating pilomatricoma shows a relatively symmetric proliferation, constituted of basaloid lobules, more or less well outlined. The cells show nuclear atypia and mitotic activity ranging from 4 to 15 mitoses / high-power field. There is, however, no perineural and/or vascular invasion $(11,12,13,15)$.

This entity is, in our opinion, very debatable, the absence of perineural and/or vascular invasion, does not exclude malignancy, even more such a brisk mitotic activity equates with malignancy. The distinction malignant versus proliferating pilomatricoma has no therapeutic implication, the treatment being the same, with a high risk of recurrence.

Malignant pilomatricoma is a low-grade malignant tumour, with local evolution and a high rate of recurrence in the absence of security margins (up to 50\%) $(4,6)$. Nodal or systemic metastases are uncommon (6).

These risks determine the treatment. Despite the lack of consensus because of its rarity, most of the authors 
advocate removal with a safe margin of 0.5 to $1 \mathrm{~cm}(4,5,6)$. Radiotherapy could be an alternative. Regular follow-up is then mandatory.

The origin of malignant pilomatricoma is still discussed: de novo or degenerating pilomatricoma? In the literature about 10 cases of malignant pilomatricomas have occurred on a classical pilomatricoma, sometimes after a very long latency of several decades, which could be construed as pleading for the second hypothesis $(4,9)$.

In our first case, the very short delay is not in favor of degeneration, it was probably a bona fide malignant pilomatricoma, despite the fact that even retrospectively we could identify formal signs of malignancy. This observation incites to great caution in interpretation of histologic slides and underlines the difficulty of the diagnosis of malignant pilomatricoma.

In conclusion, malignant pilomatricoma is a rare tumour and difficult to diagnose. It must be distinguished from benign pilomatricoma on morphological arguments. A close follow-up of elderly patients after excision of a classical pilomatricoma in order to detect eventual recurrences is probably beneficial.

\section{REFERENCES}

1. Malherbe A, Chenantais J. Note sur l'épithéliome calcifié des glandes sébacées. Prog Med. 1880; 8:826-8.

2. Lopansri S, Mihm MC Jr. Pilomatrix carcinoma or calcifiyng epitheliocarcinoma of Mahlerbe: A case report and review of the literature. Cancer. 1980; 45:2368-73.

3. Bremnes RM, Kvamme JM, Stalsberg H, Jacobsen EA. Pilomatrix carcinoma with multiple metastases: Report of a case and review of the literature. Eur J Cancer. 1999; 35:433-7.
4. Hardisson D, Lineares MD, Cuevas-Santos J, Contreras F. Pilomatrix carcinoma: A clinicopathologic study of six cases and review of the literature. Am J Dermatopathol. 2001; 23:394-401.

5. Petit T, Grossin M, Lefort E, Lamarche F, Hénin D. Pilomatrix carcinoma: Histologic and immunohistochemical features. Two studies. Ann Pathol. 2003; 23:50-4.

6. Nieddermeyer HP, Peris K, Höfler H. Pilomatrix carcinoma with multiple visceral metastases. Report of a case. Cancer. 1996; 77:1311-4.

7. Schulz T. Pilomatrix carcinoma with metastasis. Am J Dermatopathol. 2002; 24:525.

8. Fujiwara T, Yamamoto H, Hashiro M. Malignant pilomatricoma. Scand J Plast Reconstr Surg Hand Surg. 2002; 36:119-21.

9. Marrogi AJ, Wick MR, Dehner LP. Pilomatrical neoplasms in children and young adults. Am J Dermatopathol. 1992; 14:87-94.

10. Sassmanshausen J, Chaffins M. Pilomatrix carcinoma: A report of a case arising from a previously excised pilomatrixoma and review of the literature. J Am Acad Dermatol. 2001; 44:358-61.

11. Kaddu S, Soyer HP, Hödl S, Kerl H. Morphological stages of pilomatricoma. Am J Dermatopathol. 1996; 18:333-8.

12. Kaddu S, Soyer HP, Wolf IH, Kerl H. Proliferating pilomatricoma. A histopathologic simulator of matrical carcinoma. J Cutan Pathol. 1997; 24: 228-34.

13. Hague JS, Maheshwari M, Ryatt KS, Abdullah A. Proliferating pilomatricoma mimicking pyogenic granuloma. J Eur Acad Dermatol. 2007; 21: 688-9.

14. Sakai A, Maruyama Y, Hayashi A. Proliferating pilomatricoma: A subset of pilomatricoma. J Plast Reconstr Aesthet Surg. 2008; 61: 811-4.

15. Niiyama S, Amoh Y, Saito N, Takasu H, Katsuoka K. Proliferating pilomatricoma. Eur J Dermatol. 2009; 19:188-9. 